\title{
Land Use Analysis of Central Business District (CBD) of Metropolis Saddar Karachi through SRS/GIS Techniques
}

\author{
Anila Kausar ${ }^{1, *}$, Sheeba Afsar ${ }^{1}$, Zohra Wazir $^{1}$, Altaf Hussain Lahori ${ }^{2}$, Ambreen Afzal $^{1}$, Junaid Arif ${ }^{1}$, \\ Volodymyr Sydorenko ${ }^{3, *}$, Andrii Pruskyi ${ }^{3}$, Vasyl Tyshchenko ${ }^{3}$ \\ ${ }^{1}$ Department of Geography, University of Karachi, Karachi, 74000 Pakistan \\ ${ }^{2}$ Department of Environmental Sciences, Sindh Madressatul Islam University, Karachi, 74000 Pakistan \\ ${ }^{3}$ Department of Fire Prevention and Life Safety of the Civilian Population, \\ Institute of Public Administration and Research in Civil Protection, Kyiv, Ukraine \\ *corresponding author e-mail: 2022.12.gl@gmail.com; anilak@uok.edu.pk
}

Received: 25 December 2021 / Accepted: 27 January 2022

\begin{abstract}
The high density of buildings and roads are commonly associated with the Central Business District (CBD) of a metropolitan and multicultural city Karachi, Pakistan. It is the highly interactive place of a metropolis, therefore, considers functionally effective zones. This paper will prove that even with a high rate of urbanization and expansion due to urban sprawl, still Saddar is the focus of attraction concerning several facts. The main objectives of the study were to explore the land-based cataloging of Saddar based on activity and to assess the environmental issues which are associated with this land use classification for the sustainability of CBD the people perception methods of identification of research, Land-use (LU) Analysis of Area of Interest (AOI) via questionnaire-based surveying, and geo-coding of activities methods have been used in this study. The obtained results revealed that Saddar town covers land use approximately $4.28 \%$ Leisure, 9.38\% Shopping, Business or Trade, 7.9\% Social, Institutional, or Infrastructure Related, 4.62\% Mass Assembly of People, 6.37\% Industrial, Manufacturing, and Waste Related, while 5.68\% Traveler Movement, 5.9\% Natural Resource Related, 52.40\% Residential, 3.4\% No Human Activity or Unclassified. Approximately $44.2 \%$ of the land use was engaged in capita producing activities, which reflects CBD's functional strength. Overall, it recommended that there should be more green spaces in the CBD to improve air quality. Vertical urban gardening/forest can be implemented as Saddar has limited space and it is a concrete jungle having much less open space.
\end{abstract}

Keywords: Land-use Analysis; Remote sensing; GIS; Central Business District; Ecological State.

\section{Introduction}

Karachi is a metropolitan city comprised of a population of approximately 16,051,521 (Sohoo et al., 2021), a total area of $3530 \mathrm{~km}^{2}$, and a density of 4,547 per $\mathrm{km}^{2}$ (Afzal et al., 2021). By comparing existing population density Karachi that was 2648 people per $\mathrm{km}^{2}$ dense in 1998, the increase in 2099 persons per $\mathrm{km}^{2}$ in 2017. The average growth rate of metropolitan was $2.27 \%$ by the year 2020 (Nizamani, 2020). Karachi is a city which expanded in an unorganized manner and this unorganized manner is termed as the urban sprawl which is defined as "Urban sprawl, also called sprawl or suburban sprawl, the rapid expansion of the geographic extent of cities and towns, often characterized by low-density residential housing, single-use zoning, and increased reliance on the private automobile for transportation" (Ansari, 2009; Gayer, 2014). Despite the city's expansion, its historically functionally effective regions that make up "Saddar" still function as primary units (Ahmed, 2017). (Ahmed, 2017). Saddar regional coverage is approximately $21.14 \mathrm{~km}^{2}$, including civil lines subdivision, garden subdivision, and Clifton cantonment, which was included in Saddar town according to the city, district government subdivision. Including these tiers Saddar (main area), Kahkashan, City 
Railway Colony, Kharadar, Nanakwara, Old Haji Camp, Millat Nagar, and Gazdarabad are also part of Saddar and in total, there are eleven subdivisions of Saddar Region. Saddar is highly connected with the whole city through well-connected road infrastructure and it is the main hub of commercial activities with high-rise buildings, studios, cinemas, offices, etc. (Mehdi et al., 2011). The specialty of Saddar is its mixeduse development. People used to live in any particular city, because of its dynamic nature such as providing an interactive neighborhood, which provides trade and service activities (Blanco et al., 2009). The main objectives of the present study were: 1) to assess the land use (LU) of Saddar, Karachi through SRS/GIS techniques, 2) to classify the Saddar, Karachi on Land-based classification standards, 3) to identify the mobility flux towards CBD, and 4) to collect qualitative and quantitative data through questionnaire-based surveying.

\section{Methodology}

\section{Study Area}

The existing research Area of Interest is Saddar, which is the financial hub of Karachi metropolitan. Saddar contains eleven sub division administratively, i.e. Saddar, Kahkashan, Clifton,

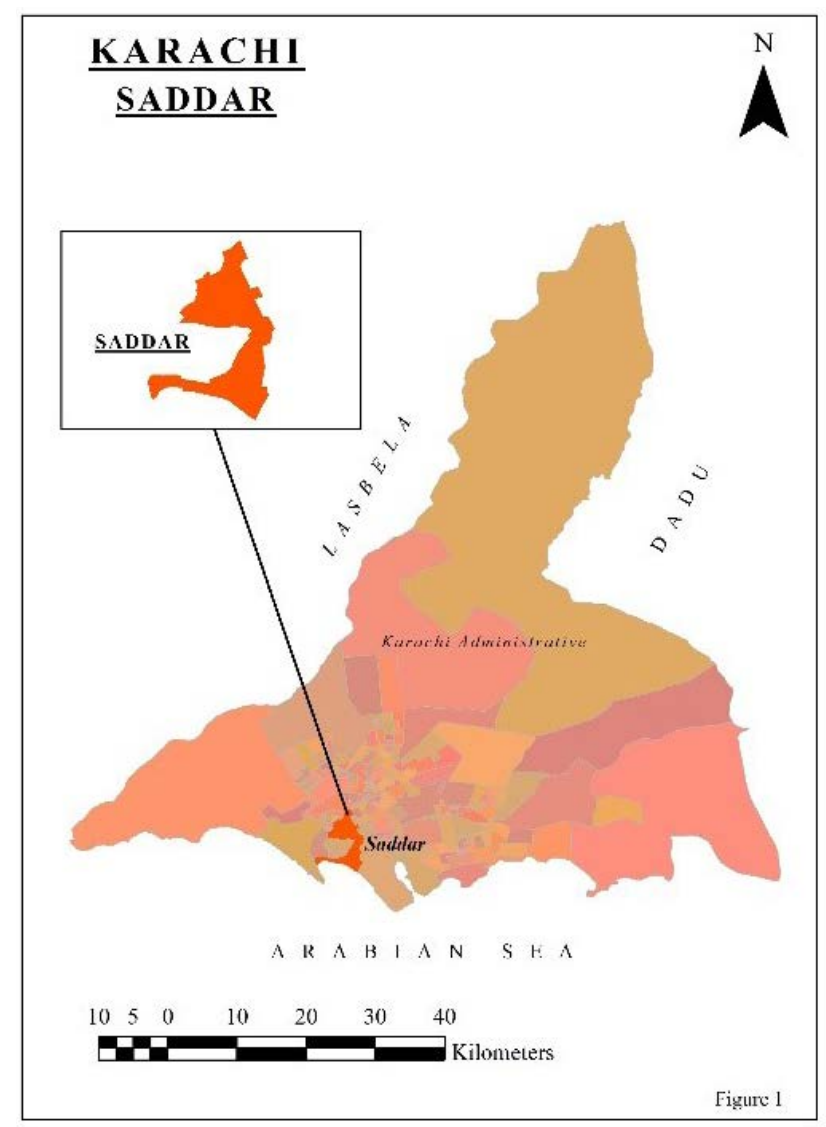

Figure 1. Map location of the study area
Civil lines, City Railway Colony, Kharadar, Nanakwara, Old Haji Camp, Millat Nagar, Garden, Gazdarabad (Figs 1 and 2).

\section{Study plan}

To access the general trends, a questionnaire was designed for person-based perception about Saddar. For quick responses, Google forms have been developed and launched (https:// docs.google.com/forms/d/10MtfSdzD1Iea393QUAqopjp IffcYKdLCo_-JZsCajuQ). A total of 124 participants have participated. Furthermore, the questionnaire was divided into several sections such as:

i) Respondent's general information \& mobility based query,

ii) Buildings and Infrastructure,

iii) Transit-oriented problems,

iv) Road traffic issues and accidents,

v) Environment and air quality issues.

To access Land-use and Land-cover (LULC) analysis for the year 2020, a very high-resolution satellite imagery (extract through SAS Planet nightly 171130.9738) has been used. Eleven administrative tiers have been superimposed on that imagery. LULC of each area has been digitized and then classified (geo-coded) on the basis of landbased classification standards. "Land-Based Classification

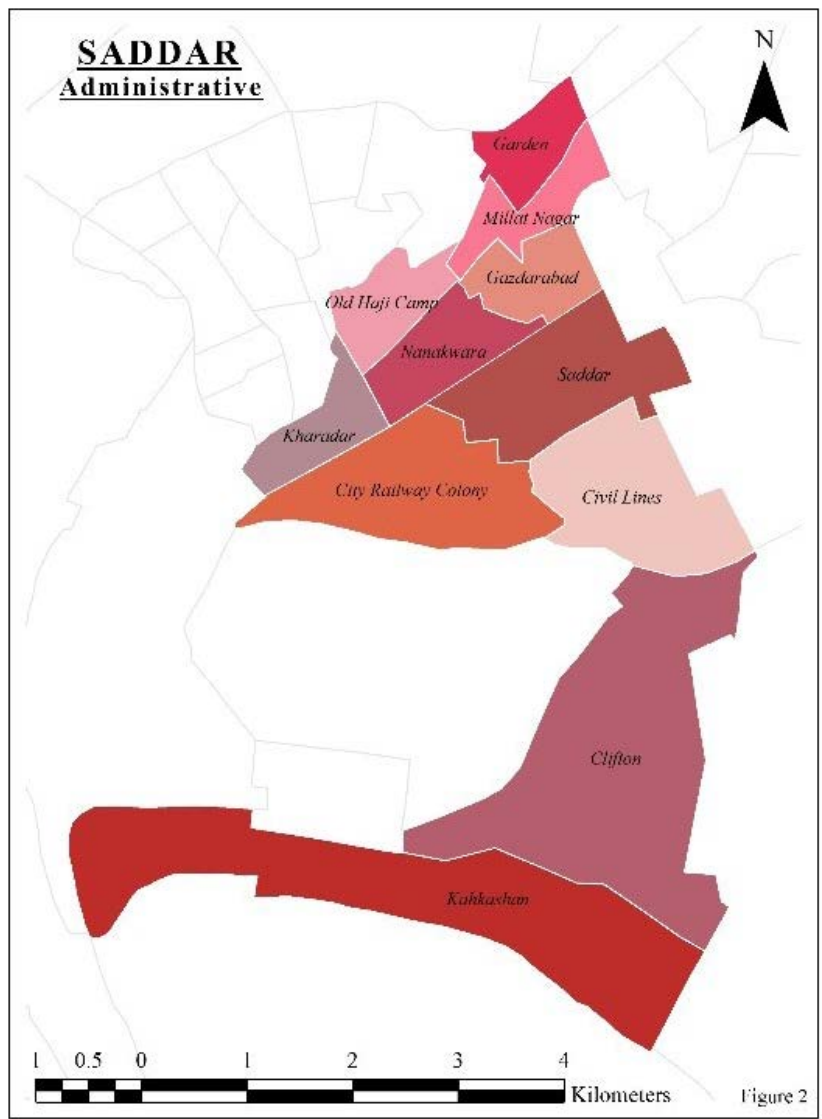

Figure 2. Saddar Administrative 
Standards provide a consistent model for classifying land uses based on their characteristics" Mirzaei et al. (2015). In addition, geo-coding was done through information through ground surveying. On the basis of activity, Land of Saddar is classified into residential activities, shopping business or trade activities, Industrial manufacturing and wasterelated activities, social institutions or infrastructure related activities, travel or movement activities, mass assembly of people, leisure activities, natural resource related activities, and no human or unclassified activity. The color coding was done based on LBC's standards set by APA in the year 2001.

\section{Result and Discussion}

According to the results, it is observed that the central business district, i.e. Saddar, has mixed use development. In the present study land use/landcover of the study area is classified into nine classes (Table 1), i.e. Leisure (LSR), Shopping, Business or Trade (SBT), Social, Institutional, or Infrastructure Related (SII), Mass Assembly of People (MAP), Industrial, Manufacturing, and Waste Related (IMW), Traveler Movement (TMT), Natural Resource Related (NRR), Residential (RSDL), No Human Activity or Unclassified (NHAU). The present study shows the Land use/Land cover (Table 2) of Saddar. According to Table 2, City Railway Colony is a highly functionally effective zone as this area holds a higher percentage of Shopping, Business, or Trade activity, i.e. $28.9 \%$ (Fig. 3).

This area mostly contains warehouses and head offices of different companies; on the one hand, Industrial, Manufacturing, and Waste related activities are also higher, i.e. $40.4 \%$, followed by Saddar $19.2 \%$ area engaged in shopping, business or trade activity. On the other hand,
Table 1. Land-Based Classification Standard

\begin{tabular}{|c|l|l|l|}
\hline S. No. & \multicolumn{1}{|c|}{ Activity } & Code & \multicolumn{1}{|c|}{ Color Code } \\
\hline 1 & Shopping, Business, or Trade & SBT & RGB 255,0,0 \\
\hline 2 & $\begin{array}{l}\text { Social, Institutional, or Infrastruc- } \\
\text { ture Related }\end{array}$ & SII & RGB 0,0, 255 \\
\hline 3 & $\begin{array}{l}\text { Industrial, Manufacturing, and } \\
\text { Waste Related }\end{array}$ & IMW & RGB 160,32,240 \\
\hline 4 & Mass Assembly of People & MAP & RGB 47,79,79 \\
\hline 5 & Leisure & LSR & RGB144,238,144 \\
\hline 6 & Travel or Movement & TMT & RGB190,190,190 \\
\hline 7 & Natural Resources-Related & NRR & RGB 34,139,34 \\
\hline 8 & Residential & RSDL & RGB 255,255,0 \\
\hline 9 & $\begin{array}{l}\text { No Human Activity or } \\
\text { Unclassifiable }\end{array}$ & NHAU & RGB255,255,255 \\
\hline
\end{tabular}

Saddar also famous for social, institutional, or infrastructure. Related activities account for $16.7 \%$, and another striking feature is the exploitation of natural resources, accounting for $12.9 \%$, being a historically effective zone. Saddar has a land which is helpful for the environment and it is a good sign for the environmental health of the region. Kharadar and Nanak Wara are also significant regions in terms of Shopping, Business, or Trade activity, i.e. $14 \%$ and $11.4 \%$ respectively.

Social, Institutional, or Infrastructure Related activities have a high rate in Civil lines where most of the five-star hotels, National Academy of Performing Art NAPA (Hindu Gymkhana), Frere Hall, Governor House, Press Club, etc. are located and approximately $25.6 \%$ of the area covered by this activity followed by Saddar where $16.7 \%$ area having Social, Institutional, or Infrastructure Related activities such as Provincial Assembly of Sindh, Sindh Secretariat, Colleges,

Table 2. Activities coverage area (\%)

\begin{tabular}{|c|c|c|c|c|c|c|c|c|c|c|}
\hline S. No & Study Area & LSR & SBT & SII & MAP & IMW & TMT & NRR & RSDL & NHAU \\
\hline 1 & City Railway Colony & 1.9 & 28.9 & 2.21 & 0.54 & 40.4 & 6 & 7.36 & 12.7 & 0.1 \\
\hline 2 & Saddar & 0.11 & 19.2 & 16.7 & 6.54 & 0.2 & 4.46 & 12.9 & 40 & 0 \\
\hline 3 & Kharadar & 0.7 & 14 & 2.71 & 5.9 & 0 & 2.6 & 3.1 & 70.12 & 1 \\
\hline 4 & Nanak Wara & 5.22 & 11.4 & 14.4 & 2.13 & 0.14 & 2.58 & 4.24 & 59.76 & 0.2 \\
\hline 5 & Clifton & 11.1 & 8.6 & 5.41 & 0.65 & 0 & 16.1 & 3.05 & 39.15 & 15.93 \\
\hline 6 & Gazdarabad & 3.39 & 8.1 & 9.69 & 2.23 & 0 & 5.8 & 11.85 & 57.78 & 1.21 \\
\hline 7 & Civil Lines & 19.2 & 6.25 & 25.6 & 2.31 & 1.75 & 11.6 & 6.02 & 27.22 & 0 \\
\hline 8 & Khekashan & 5.28 & 2.8 & 3.22 & 1.11 & 13 & 2.1 & 3.53 & 59.7 & 9.49 \\
\hline 9 & Millat Nagar & 0.13 & 1.7 & 4.11 & 2.3 & 0 & 5.35 & 8.21 & 69.55 & 8.7 \\
\hline 10 & Garden (East) & 0 & 1.24 & 2.57 & 26.2 & 0 & 5.8 & 3.5 & 59.23 & 1.5 \\
\hline 11 & Old Haji Camp & 0.1 & 1 & 0.74 & 1 & 14.6 & 0.11 & 1.21 & 81.24 & 0.1 \\
\hline
\end{tabular}




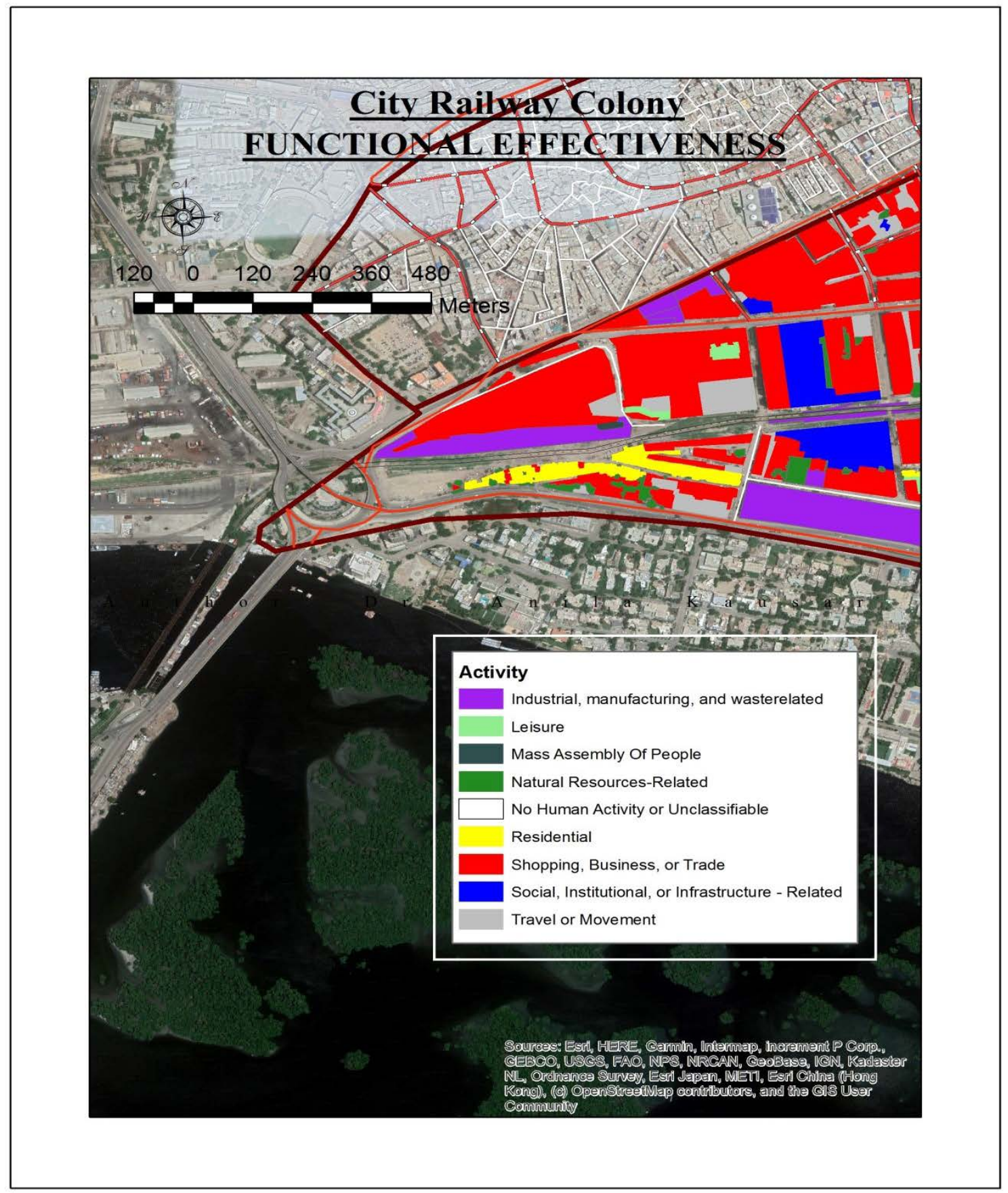

Figure 3. City Railway Colony

famous schools, courts, etc. Nanakwara is also famous for social, institutional, or infrastructure related activities, i.e. $14.4 \%$. The prime attraction place is Karachi Metropolitan Cooperation (KMC) Building.

The highest mass assembly of people is at Gazdarabad which is $26.2 \%$ coverage area. It contains Church, Masjids, a Sports Complex, etc. The concentration of Industrial, Manufacturing, and waste related is in city railway colony, i.e. $40.4 \%$, the area is connected with the seaport (Fig. 4). As mentioned earlier, the area also holds a higher percentage of shopping, business and/or trade activity so collectively $69.3 \%$ of the area is related to the industrial, manufacturing, and waste related and shopping, business or trade activity. It is the highest percentage in any administrative division within the Saddar. Old Haji Camp is 2nd most importation administrative division in the category of industrial, manufacturing, and waste related activity, i.e. $14.6 \%$.

In the category of travel and movement (excluding roads and streets) all kinds of travel and movement activities are included: guesthouses, hotels, travel agencies, car parking, 


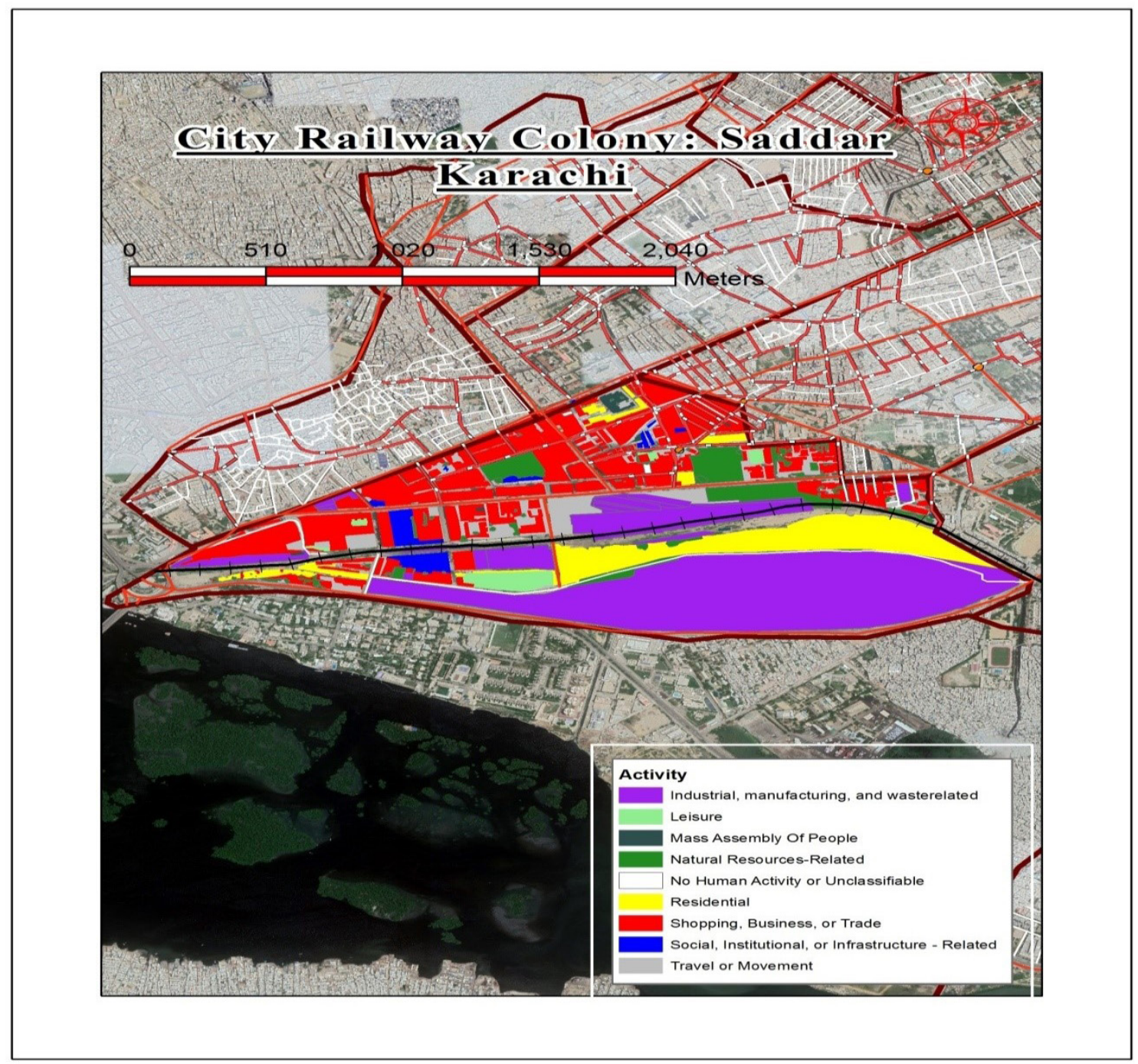

Figure 4. City Railway Colony

etc. Clifton (Fig. 5) is the high standard residential area of the region and here $16.1 \%$ of land use was occupied by travel and movement activities, followed by civil lines (11.6\%), where Karachi's most of the five star hotels are located (Fig. 6).

As observed data revealed in Old Haji Camp (Fig. 7), Kharadar (Fig. 8), Millat Nagar (Fig. 9), Nanakwara (Fig. 10), Kehkashan (Fig. 11), Garden East (Fig. 12), and Gazdarabad (Fig. 13), have residential activity on more than $50 \%$ of its land, i.e. $81.24 \%, 70.12 \%, 69.55 \%, 59.76 \%, 59.7 \%, 59.23 \%$, and $57.78 \%$ respectively. Saddar (Fig. 14), and Clifton have $40 \%$ and $39.14 \%$ respectively in which Saddar is a vast and famous area of megacity Karachi, the main focus of attraction for the people from every area of Karachi. Civil lines are observed by $22.22 \%$ residential activity, while City Railway Colony has $12.7 \%$ residential area and most of its area is included in trade activities. Natural Resources-Related activities were observed higher in Gazdarabad and Saddar respectively. Both kinds of trees coverage areas and lawns are included in this category in both regions. As Little (APA, 2001) observed, a linear open space is a greenway. Its function is reducing pollution, subsiding noise, augmenting microclimatic properties (Little, 1995). Though the percentage is not very high in the study area, even then it is a good sign greenway exists in CBD. It is very important that we go towards a nature-based solution to mitigate the issues of air pollution and should introduce the art of designing buildings with green roofs and wall installations, should be planned to increase green spaces in terms of parks and established green belts along the roads.

\section{People's Perception}

To identify people's perception of the Saddar (Fig. 14), a questionnaire was launched through the Internet. Most of the questions are close-ended, while a few questions are left for open-end and the reason is to find suggestions on a particular topic. 124 responses have been recorded. 

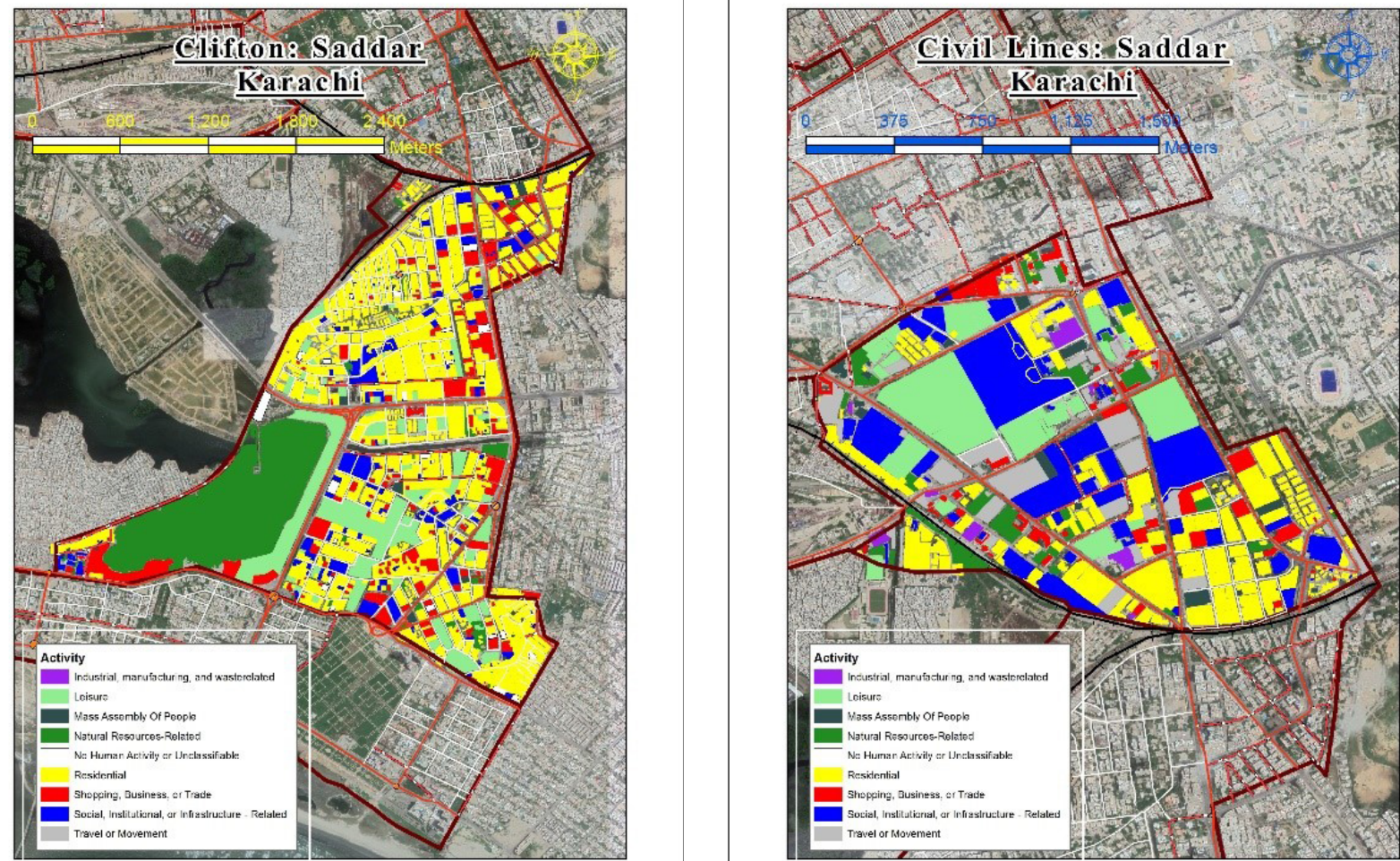

Figure 5. Clifton

Figure 6. Civil Lines

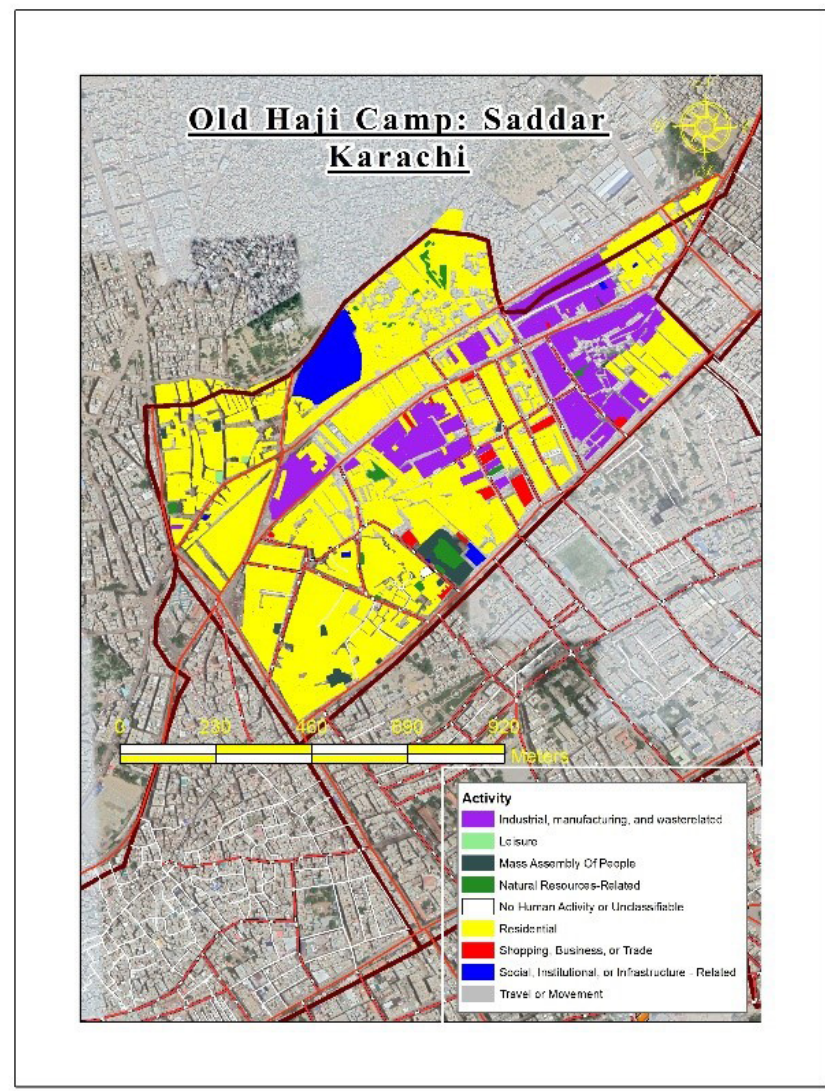

Figure 7. Old Haji Camp

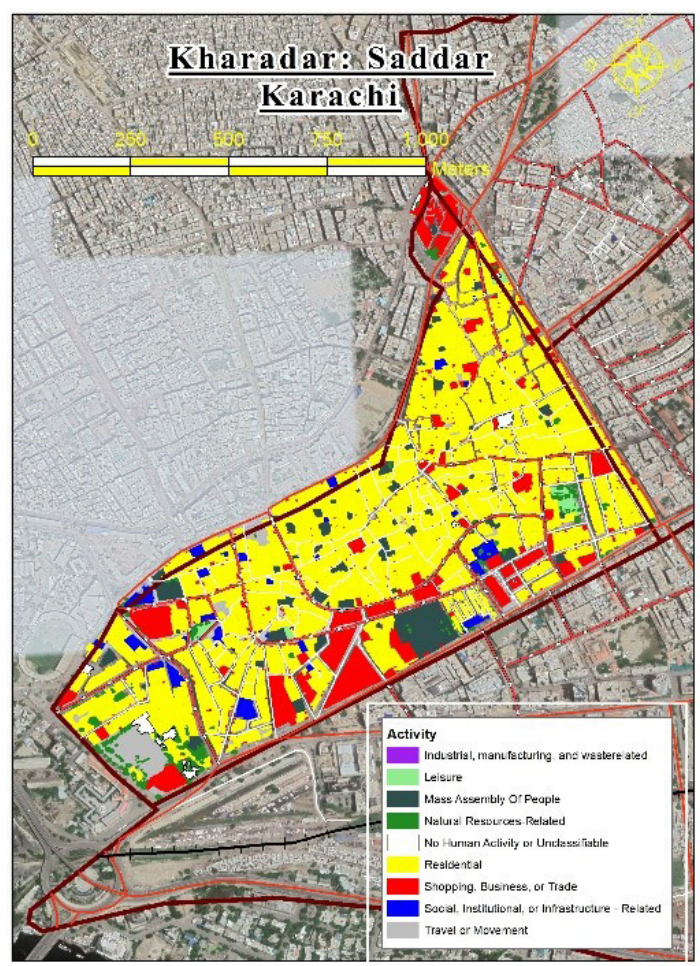

Figure 8. Kharadar 


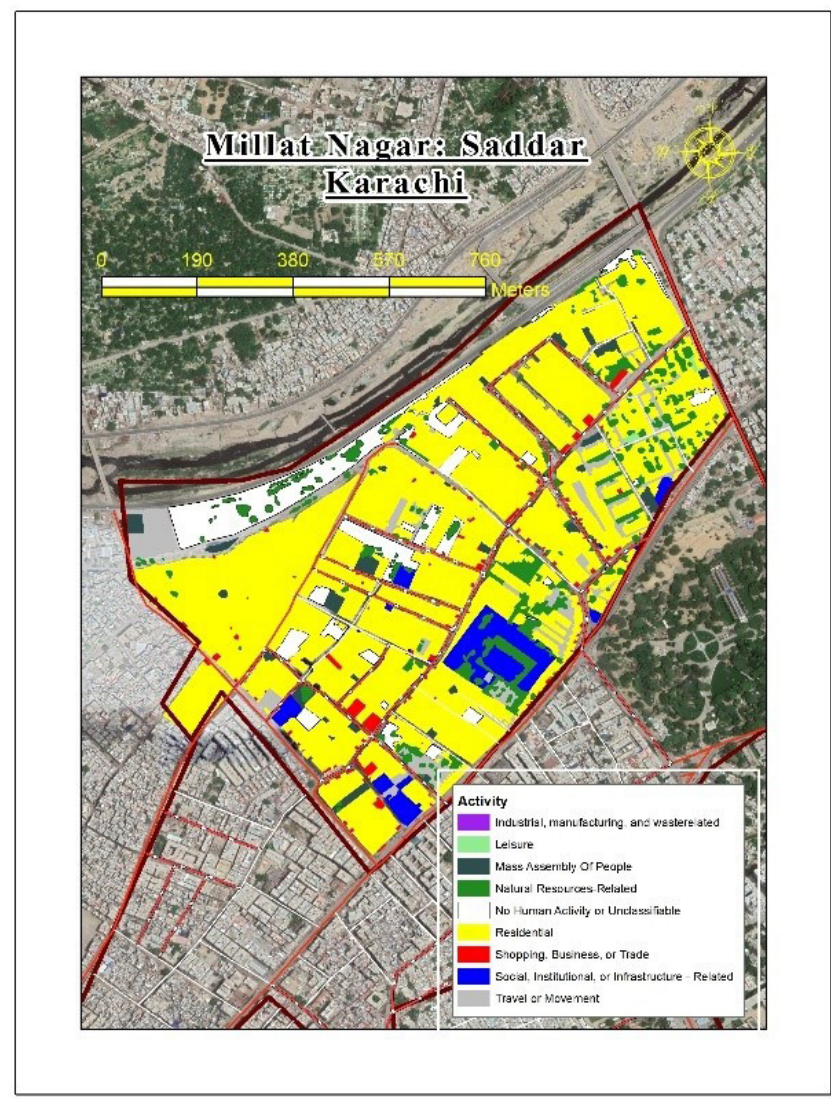

Figure 9. Millat Nagar

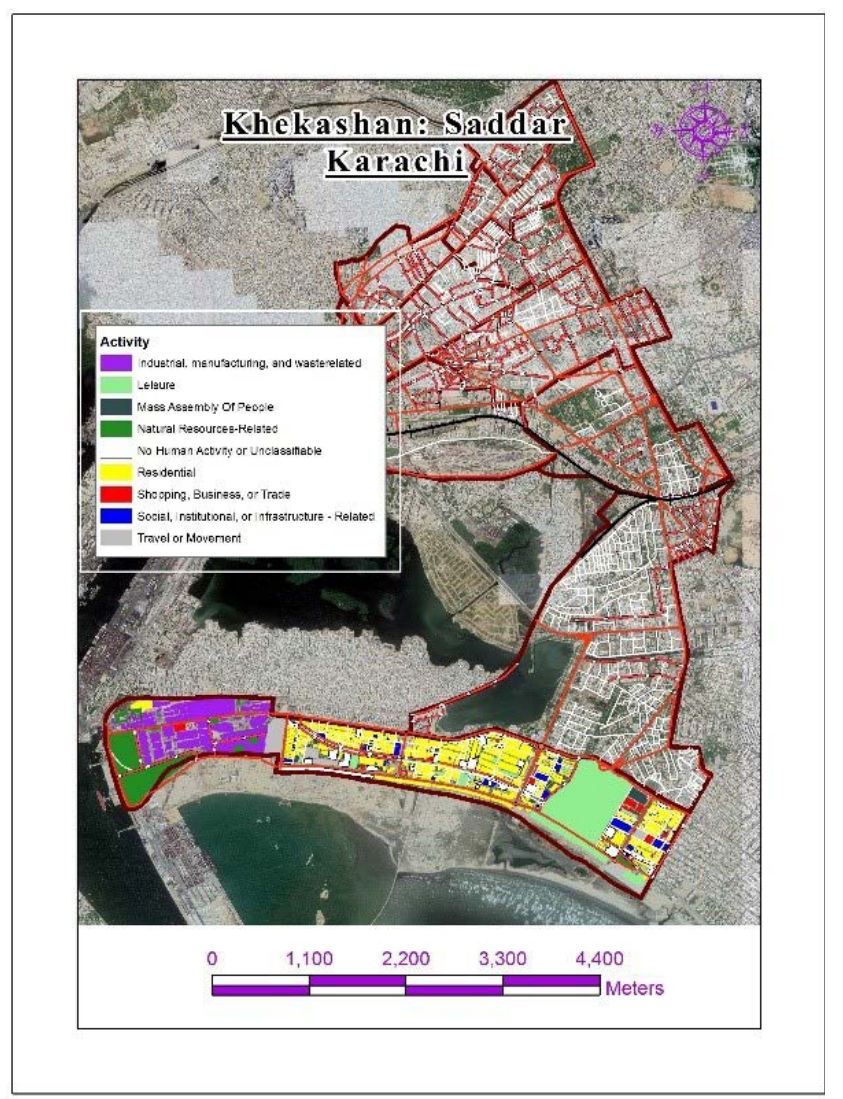

Figure 11. Khekashan

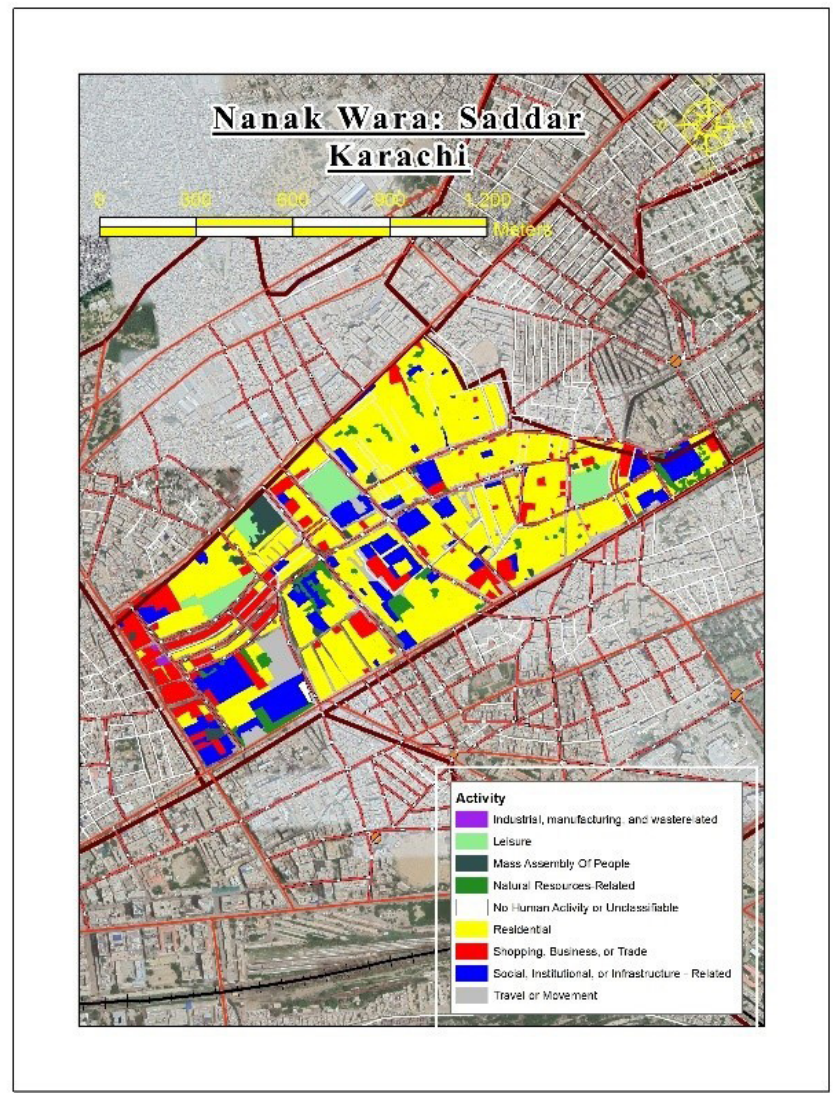

Figure 10. Nanak Wara

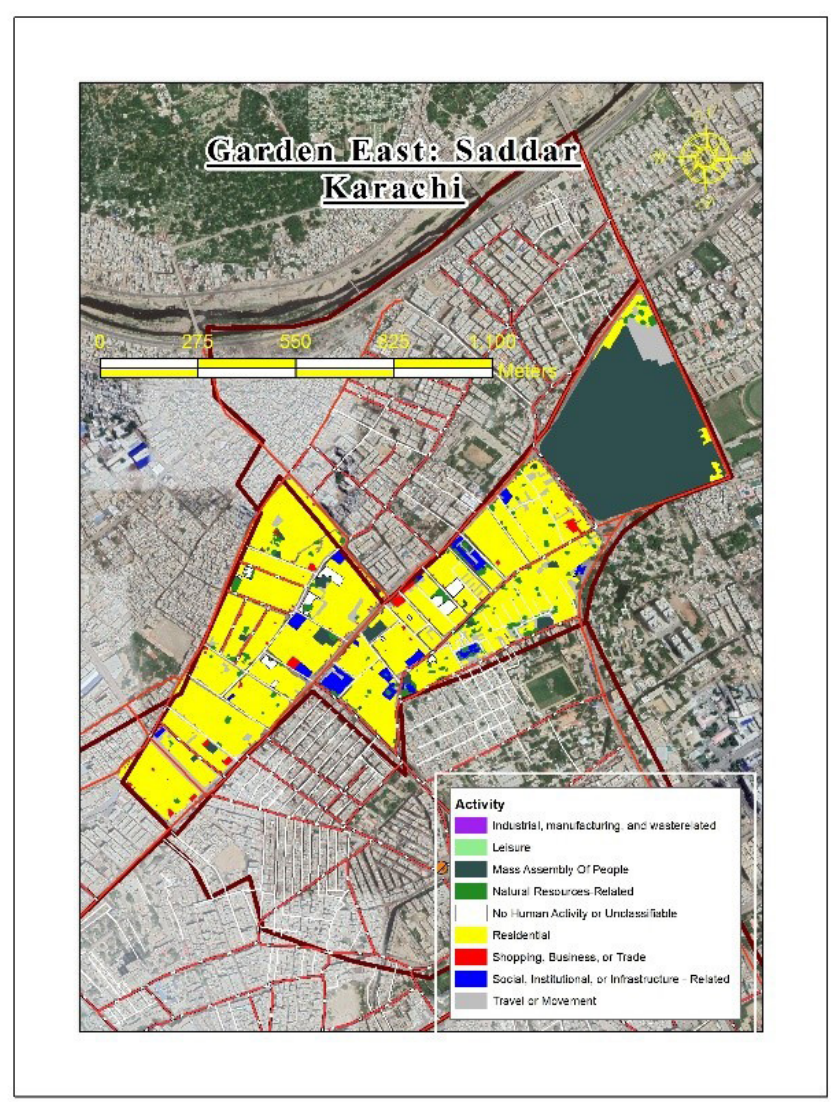

Figure 12. Garden East 


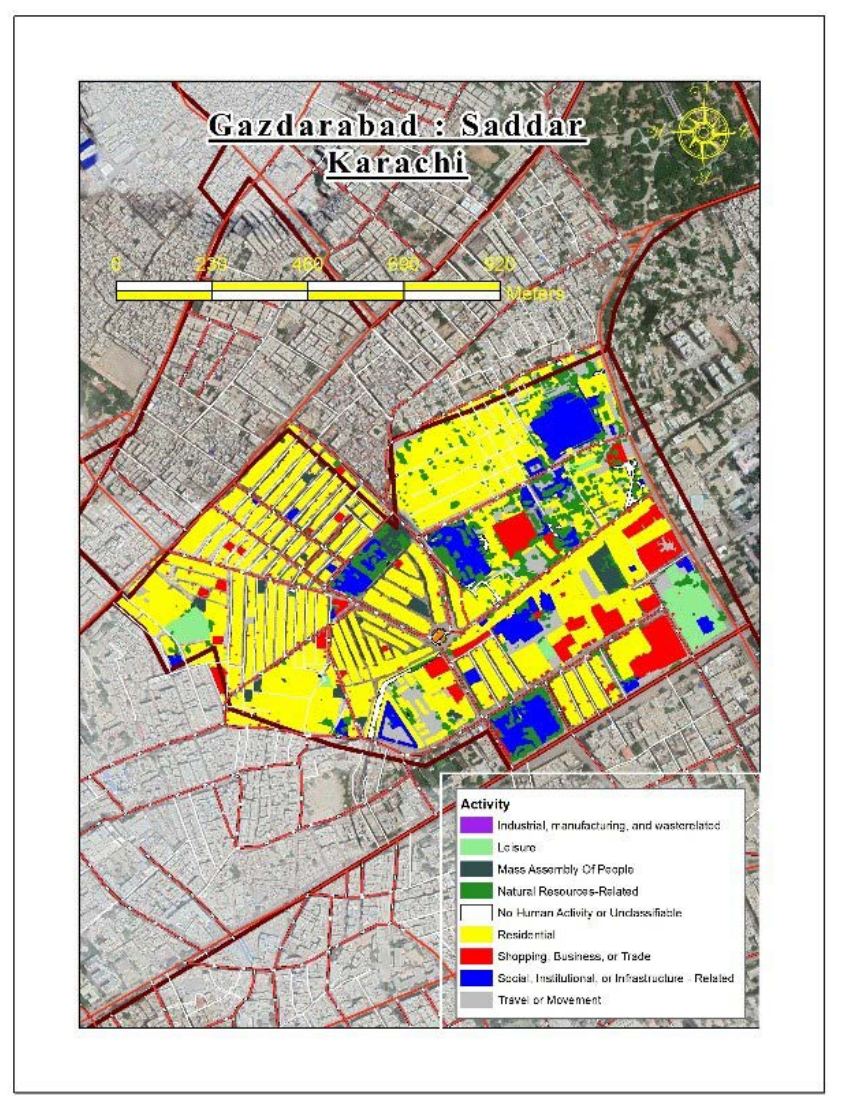

Figure 13. Gazdarabad

Approximately 122 respondents responded with occupation status. About $76 \%$ were students, $32 \%$ employees, $11 \%$ housewives, $7 \%$ businessmen, $5 \%$ online sales/purchasers, while $4 \%$ freelancers participated in the survey. Out of 124 , 62 respondents have office/business setup/studio/shop/ trade office located in Saddar. In addition, 34\% have their timings 9:00am-5:00pm, while the maximum stay was up till midnight. After midnights, every shopping, business, and trade activity close in Saddar. Furthermore, 116 respondents replied on how often they visited Saddar; options were daily, once a week, twice a week, once in a month, twice in a month, once in six months, once in a year and the answers are $5.2 \%$, $9.5 \%, 6 \%, 18.1 \%, 4.3 \%, 27.6 \%$, and $31.9 \%$ respectively, and the reason for their visits are for sale purchase, shopping, watching a movie, watching drama in the theatre, visiting food street, photography and press club. $73.6 \%$ people came to Saddar for shopping purposes, $29.1 \%$ for sale and purchase, 15.5\% came here to visit Food Street, 9.1\% people have visited Saddar for leisure purposes as well, i.e. they came here for watching movies and dramas in cinemas and theatres. As Saddar has old building structures, the people visited here for photography purposes too. Though percentage was comparatively low, i.e. 3.6\%, even then it is a healthy activity and people are involved in it. Saddar also has a press club

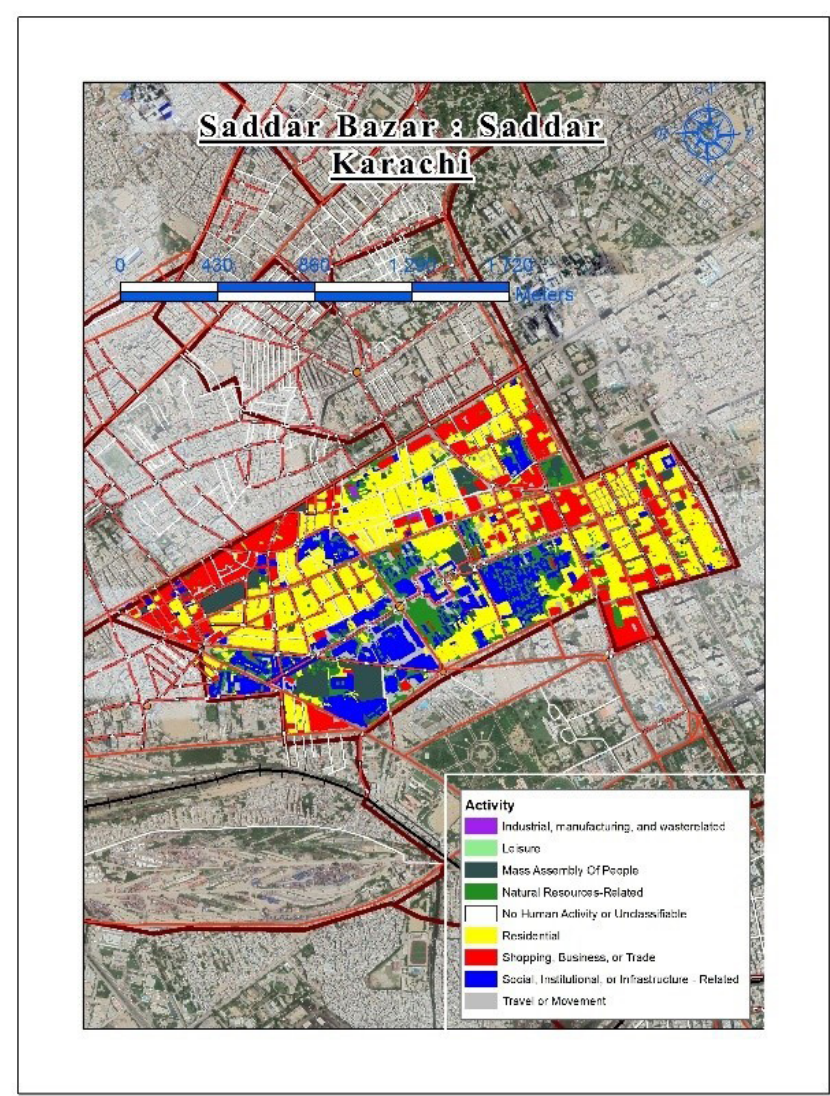

Figure 14. Saddar

and even buildings of different Media groups; therefore, it is a daily visit place of media personalities as well.

New planning discourses and practices typically lie at the nexus of higher urban density, improved infrastructure, new city center retail complexes, mixed use, and creative design of public space (Bischoff, 1995). For the shopping mostly (59.2\%) people visit here for clothes, followed by mobile purchasing (50.5\%), shoe shopping (35\%), laptops (32\%), other electronic items (25.2\%) crockery items (14.6\%), $11.7 \%$ for sports item, for both gold jewelry item and artificial jewelry items $10.7 \%$, for purchasing birds and animals $7.8 \%$, books (2.9\%). Other reasons for shopping are art supplies, automobiles, groceries, furniture, etc. The most visited markets are Zainab Market (54.8\%), Jama Cloth (40.9\%), Mobile Market (36.5\%), Gull Plaza (30.4\%), Atrium (27\%), Regal (26.1\%), Boltan Market (26.1\%), and Mehboob Market (8\%). $91.7 \%$ of respondents think that prices of items in Saddar are relatively lower than on other markets in Karachi. $40.3 \%$ of people visited five-star hotels in Saddar. $47.1 \%$ came here for attending official meetings/ conferences. $45.1 \%$ for attending any party/concert, $35.3 \%$ for dinner/lunch etc. However, only $27.5 \%$ of people visited press clubs at any time but $57.3 \%$ of respondents think that Press Club is located in the best suitable place. $79.5 \%$ think 
there should be more car parking required in the study area. $63.8 \%$ strongly believe there should be greener spaces (urban forest/parks/greenways) in the city center. $89.8 \%$ of people have aesthetic sense and they like old (historical) structures in Saddar. Among the old structure places, Empress Market is mostly visited. $78.3 \%$ people like tall buildings and $83.3 \%$ people of those visited who Saddar have an issue with car parking within the building. $98.3 \%$ of people believe that car parking along each building is mandatory.

Travel and movement is the main issue of the study area. Though Saddar is the most visited place, even walkers have a serious issue with walking on the streets of Saddar and 88\% of people face walking issues; according to them, the CBD should have a walkable place. The main reason for obstacles in walking is too much traffic flow; $80.7 \%$ of respondents face traffic hinderers during walking. Approximately $68.8 \%$ gave the reason for walking issues that too many cars/bikes are parked along roads and nearly $40.4 \%$ complain that the footpaths are not available. $25.7 \%$ complain pedestrians are not available, $17.4 \%$ complain about the traffic constables that are not available with every road. $87.1 \%$ demanded that service roads availability is a must along each main road.

To improve access to services and facilities, to decrease car dependency (a social excluder for those without a personal vehicle), to increase the potential for spontaneous interaction and to create a sense of community in neighbourhoods (Bischoff, 1995; Bramley \& Power, 2009; Getu \& Bhat, 2021 ). It was observed that about $28 \%$ of people believe in mixed use development, while $34.7 \%$ strongly believe that Saddar should be for commercial activities only. $65.3 \%$ of respondents who are residents of Saddar said they have not faced any difficulty living here.

Sustainable communities are places that meet the diverse needs of existing and future residents, or more specifically, that these are places where people want to live and work and that contribute to a high quality of life: they are safe and inclusive, well planned, built and run, and they offer equality of opportunity and good services for all (Burton, 2000). About $68.9 \%$ of respondents are certain that there is no proper drainage system on Saddar main streets. About $89.4 \%$ complained the water was standing on the roads during recent urban flooding of the year 2020. Approximately $25.3 \%$ of people reported that their entire legs were underwater, $63.3 \%$ reported that water reached their knees, while $8.1 \%$ said that the flood reached the face level, i.e. above chest. It was noted that about $40.2 \%$ of the people observed the disappearance of water within three days after the flood. Meanwhile, 34.3\% witnessed water vanishing in a week, while $25.5 \%$ people complained that water was standing on roads of CBD for more than a week.

The most striking aspect of Karachi's layout is the westto-east parallel alignment of the four arterial roads: Nishter
Road (formerly called Lawrence Road), Mohammed Ali Jinnah Road (formerly Bandar Road), Shah rah-e-Liaquat (Frere Road), and I. I. Chandigarh Road (McLeod Road) (Dempsey et al., 2011). People mostly visited CBD on bikes and cars, i.e. $37.4 \%$. Shahara e Faisal was most regularly used for travel to $\mathrm{CBD}$, i.e. $46.5 \%$. The obtained data showed that $43 \%$ used University Road, $15.8 \%$ used Shahra e Pakistan, 10.5\% Layari Express Way, 7\% use other roads, i.e. M. A. Jinnah Raod, Maripur road, and I. I. Chundrigar road. Only $6 \%$ of people's travel time exceeds an hour, $14 \%$ consumes 50 minutes to 1 hour, $21 \%$ consumes 40 minutes, $23 \%$ consumes half an hour, $22 \%$ consumes even less than 30 minutes. Moreover, $82.8 \%$ of the regular visitors of Saddar witnessed 1 to 3 traffic accidents on a daily basis. Among them, 13.8\% also experienced an accident on the road of CBD near Electronic market, Empress Market, and II Chundarigar road. $58.8 \%$ criticized the traffic congestion on the roads of CBD. According to $16.7 \%$ of people, air pollution is the main problem of $\mathrm{CBD}$, while $22.8 \%$ complained about the noise pollution. $74.3 \%$ of people's perceptions about the signals on the roads of CBD are not enough. It was observed that about $40.7 \%$ of people experienced an anxiety issue when they visited CBD. 33\% experienced eye infection, $17.6 \%$ experienced blood pressure issue, $15.4 \%$ experienced asthma, $12.1 \%$ experienced headache, migraine, tiredness, and feeling of vomiting, $11 \%$ experienced sinus issue, $7.7 \%$ experienced influenza, 5.5\% believed they got COVID-19 infection after visiting CBD. 73.3\% respondents complained about the CBD environment, i.e. dusty, $46.6 \%$ complained about the smoky environment and there are fewer (3.4\%) perceptions that the CBD is clear, while $87.8 \%$ firmly believe in noise pollution exerting a major impact on CBD's life. 91.2 percent of people who believed in tree plantations derive from the CBD. Furthermore, approximately $33 \%$ of people said there has been no increase in the number of trees within the CBD for a long time. It was revealed that $35.7 \%$ believed in an increase in trees, while 31.3 believed there is a decline in trees. In addition, nearly $60 \%$ do not like the idea of any other type of green cover, e.g. grass/decorative plants can be the replacement of old trees. About the Air Quality of Saddar people arbitrated in worst (38.8\%, very bad (33.6) and bad (23.3\%) situation. 13\% people have not got any hope that air quality index of Saddar will be better in the future. $47 \%$ consider the situation can be changed, while $40 \%$ strongly believed that Air Quality index will be better in the future. It was noted that about $60.4 \%$ of people experienced smog within CBD mainly in the months of December (50\%) January (36.8\%). 


\section{Conclusion}

Land-use/Land cover (LULC) of CBD were analyzed in the present study using very high resolution satellite imagery extracted through SAS Planet nightly 171130.9738 and ground survey data. Land-use classes were obtained on the basis of land based classification standards. Along with the LULC analysis a questionnaire was also developed to know the people's perception of the CBD. The results show that the largest metropolis of Pakistan, Karachi, has a CBD, i.e. Saddar, implementing mixed-use development, where residential activity predominates in addition to central functional activities. This is a good sign as the developed world is introducing a walking distance approach to improve the living environment and health in Saddar in such a way as to counteract the degradation processes of $\mathrm{CBD}$ in the largest metropolitan city of Pakistan. The methodology developed in this study was observed useful in the mapping of land-use of the study area and also the present current scenario of CBD.

\section{Future suggestions and Recommendations}

To avoid traffic congestion, the transportation network should be improved. Transit-oriented design can be implemented as Saddar can link with the Lyari Expressway efficiently on the one hand, while it is also planned to connect with the green line project on the other hand.

More recreational functions should be introduced, except for the city lines and the Clifton sub-division, as there are far fewer recreational activities elsewhere in the CBD.

As Leisure, Shopping, Business, or Trade, Social, Institutional, or Infrastructure Related, Mass Assembly of People, Industrial, Manufacturing, and Waste Related, Travel or Movement, Natural Resources-Related are the indicators of economic functionality and their contribution was $44.2 \%$ as a whole, even after the exclusion of areas which are in use for transportation networks. Therefore, it reflects the $\mathrm{CBD}$ of Karachi metropolitan is functionally effective. It can be more improved if the Land-use planning strategies can be implemented. Such as transit, orient designs (TOD) to improve transportation facilities and green spaces/ greenways to improve air quality and ultimately the health of the residents and daily visitors of CBD.

The mixed development in $\mathrm{CBD}$ once again leads to the conclusion that commercial, residential, cultural, institutional and industrial uses are the basic indicators of economic functionality. In this situation, it is very important to introduce pocket parks or mini parks to improve the ecological condition of the CBD in Karachi. It is very important to introduce pocket parks or mini-parks to improve the ecology state of the CBD of Karachi. These pocket parks can fulfill the requirement of small event space, play areas for children, spaces for relaxing, meeting friends or taking lunch breaks.

\section{Acknowledgment}

The authors' team is thankful to the students who were part of this project. Their names are Sidra Sherwani, Shahid Hussain, Umaima Nadeem, Tanzeela Moin, Warisha Khan, Qurat ul Ain, Himaliya Bibi, Nida Rafique, Sara Mujahid, Rameen Tayyaba, Muntaha Fatima, Shagufta Jamil, Sadia Talha, Shafique Ur Rehman, Wajiha Ashraf, and Sharmeen Arif. The authors' team is much obliged to the chairman of the Department of Geography, University of Karachi Prof. Dr. Shamshad Akhtar who provided lab facilities throughout the project work. The authors' team is also thankful to Chaudhry Wasif Mehmood for capturing pictures of Saddar.

\section{References}

Afzal A., Afsar, S. \& Lahori A.H., 2021, Solid waste management practice in Karachi through GIS techniques. Pure and Applied Biology 10: 1258-1278. http://dx.doi. org/10.19045/bspab.2021.100132.

Ahmed N., 2017, Colonial encounters, Karachi and AngloIndian dwellings during The Raj (Master's thesis, Middle East Technical University). Available: http://etd.lib.metu. edu.tr/upload/12620710/index.pdf.

Ansari J., 2009, Revisiting urban planning in South Asia. Global Report on Human Settlements, 20. Available: https://mirror.unhabitat.org/downloads/docs/ GRHS2009RegionalSouthAsia.pdf

APA, American Planning Association, 2001. https://www. planning.org/lbcs/

Bischoff A., 1995, Greenways as vehicles for expression. Landscape and Urban Planning 33(1-3): 317-325.

Blanco H., Alberti M., Olshansky R., Chang S., Wheeler S.M., Randolph J., London J.B., Hollander J.B., Pallagst K.M., Schwarz T. \& Popper F.J., 2009, Shaken, shrinking, hot, impoverished and informal: Emerging research agendas in planning. Progress in Planning 72: 195-250.

Bramley G. \& Power S., 2009, Urban form and social sustainability: The role of density and housing type. Environment and Planning B: Planning and Design 36(1): 30-48. https://doi.org/10.1068/b33129.

Burton E., 2000, The potential of the compact city for promoting social equity, [in:] K. Williams, L. Burton, M. Jenks (eds.), Achieving sustainable urban form, pp. 19-29. F \& FN Spon, London.

Dempsey N., Bramley G., Power S. \& Brown C., 2011, The 
social dimension of sustainable development: Defining urban social sustainability. Sustainable Development 19(5): 289-300. https://doi.org/10.1002/sd.417.

Gayer L., 2014, Karachi: Ordered disorder and the struggle for the city. Oxford University Press (UK).

Getu K. \& Bhat H.G., 2021, Analysis of spatio-temporal dynamics of urban sprawl and growth pattern using geospatial technologies and landscape metrics in Bahir Dar, Northwest Ethiopia. Land Use Policy 109: 105676.

Little C.E., 1995, Greenways for America. The Johns Hopkins University Press, London, 237p. ISBN: 0-8018-5140-8.

Mehdi M.R., Kim M., Seong J.C. \& Arsalan M.H., 2011, Spatio-temporal patterns of road traffic noise pollution in Karachi, Pakistan. Environment international 37(1): 97-104.
Mirzaei M., Yazdanfar S.-A. \& Khakzand M., 2015, Mixed use development, a solution for improving vitality of urban space. Environment and Urban Systems 42: 1-13.

Nizamani J.A., 2020, Assessment of different hazards and vulnerabilities with sparse data in coastal city of Karachi, Pakistan (Master's thesis, Middle East Technical University, July 2020). Available: https://open.metu.edu. tr/bitstream/handle/11511/69257/12625634.pdf

Sohoo I., Ritzkowski M., Heerenklage J. \& Kuchta K., 2021, Biochemical methane potential assessment of municipal solid waste generated in Asian cities: A case study of Karachi, Pakistan. Renewable and Sustainable Energy Reviews 135: 110175. 